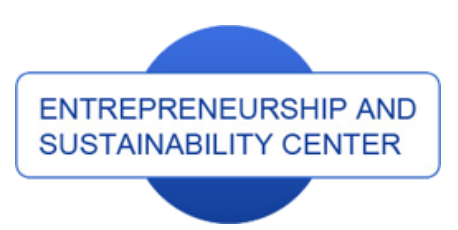

Publisher

http://jssidoi.org/esc/home enterprise

europe

network

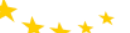

Business Support on Your Doorstep

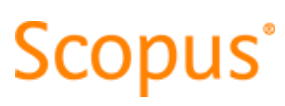

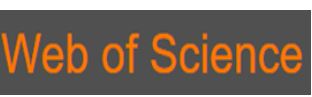

Clarivate

Analytics

\title{
THE EFFECT OF CLUSTERS ON THE INNOVATION PERFORMANCE OF ENTERPRISES: TRADITIONAL VS NEW INDUSTRIES*
}

\author{
Miroslav Žižka ${ }^{1}$, Vladimíra Hovorková Valentová ${ }^{2}$, Natalie Pelloneová ${ }^{3}$, Eva Štichhauerová ${ }^{4}$ \\ 1,2,3,4 Technical University of Liberec, Faculty of Economics, Studentská 2, CZ 46117 Liberec 1, Czech Republic \\ E-mails. ${ }^{1}$ miroslav.zizka@tul.cz; ${ }^{2}$ vladimira.valentova@tul.cz; ${ }^{3}$ natalie.pelloneova@tul.cz; ${ }^{4}$ eva.stichhauerova@tul.cz
}

Received 27 February; accepted 25 March; published 30 June 2018

\begin{abstract}
The present paper assesses the effect of the formation of cluster organisations on the innovation performance of member enterprises in two different industries - the traditional textile manufacturing industry and the new nanotechnology industry. Innovation performance is explored using Data Envelopment Analysis in two phases. In the first phase, it examines the ability of enterprises to transform resources (labour force, long-term capital, intellectual capital) into registered industrial property rights: patents, utility models, industrial designs, and trademarks. In the second phase, it assesses the ability of enterprises to commercialise industrial property rights and generate profits. Innovation performance then integrates both phases. In each industry, two samples were assessed: member enterprises of cluster organisations, and enterprises that operate in the same industry and region but are not members of a cluster organisation. The results of the research show that the existence of a cluster organisation has a greater effect on innovation performance in the traditional textile manufacturing industry. In contrast, in the new nanotechnology industry, the existence of a cluster organisation did not prove to have any significant effect on innovation effectiveness. In this industry, the existence of a cluster organisation had only a partial effect related to better industrial property rights commercialisation. Research shows that the type of industry is an important factor in the innovation performance of clustered enterprises.
\end{abstract}

Keywords: cluster organisation, industry cluster, textile cluster, nanotechnological cluster, innovation performance, innovation effectiveness, innovation efficiency, data envelopment analysis

Reference to this paper should be made as follows: Žižka, M.; Hovorková Valentová, V.; Pelloneová, N.; Štichhauerová, E. 2018. The effect of clusters on the innovation performance of enterprises: traditional vs new industries, Entrepreneurship and Sustainability Issues 5(4): 780-794. http://doi.org/10.9770/jesi.2018.5.4(6)

JEL Classifications: C61, L67, O32

*The research was conducted with the financial support of Czech Science Foundation grant no. GA18-01144S entitled "An empirical study of the existence of clusters and their effect on the performance of member enterprises".

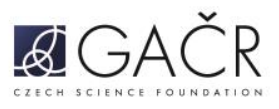




\section{Introduction}

Clusters are today considered to be one of the main instruments of regional policy used to create regional innovation systems. Since the 1990s, there has been a shift in the very concept of a cluster. From the original concept of a cluster as the geographical concentration of enterprises, universities, research institutes, professional organisations, and regional development agencies in a given territory, which benefits the actors in the form of economies of agglomeration, cluster organisations are now purposely established through cluster initiatives (Vasiljeva, 2013a). The formation of cluster organisations is often initiated by government bodies and supported using public funds. In the Czech Republic, the formation of cluster organisations has been supported since 2004, when the first Operational Programme Industry and Enterprise was approved; it included a sub-programme to support clusters (CLUSTERS). This was followed in 2007-2013 by the subsequent Operational Programme Enterprise and Innovation, which included the Cooperation sub-programme, and since 2014 on-going support for cluster organisations has been provided within the Operational Programme Enterprise and Innovations for Competitiveness. Since 2004, CZK 2.7 billion has been spent to support the formation and operation of cluster organisations in the Czech Republic (CzechInvest 2018). Therefore, the question of the effectiveness and efficiency of such public spending is important. In this case, effectiveness is understood to be the ability to achieve the objective of subsidy support, i.e. to improve the innovation performance of enterprises within clusters. Efficiency is then understood as accomplishing this objective with the least possible inputs.

The research aims to determine whether cluster organisations have a significant effect on the innovation activities of member entities. Innovation activities are measured by the number of patents, including European patents, utility models, industrial designs, and trademarks. Two industries were selected, one representing one of the Czech Republic's traditional industries (the textile and apparel industry) and the other representing the new area of nanotechnology. In each industry, two samples were defined - innovation enterprises in a cluster organisation and enterprises operating outside a cluster organisation in the given region. The research aims to verify the hypothesis that enterprises in a cluster organisation (in both industries) show better innovation performance than enterprises outside the cluster.

Data Envelopment Analysis (DEA) is used as the tool to measure effectiveness and efficiency. This is a multiple criteria linear programming method that assesses the relative efficiency of decision making units (DMUs) using multiple inputs and outputs (Zhu 2014). For each unit, such weights of inputs and outputs are sought as to maximise its efficiency. It should be noted that for the DEA method, the concept of efficiency is understood as being technical. In specific applications, the calculated value can also be interpreted as effectiveness or performance. A unit's efficiency rate is determined as the ratio of the weighted sum of outputs to the weighted sum of inputs. DMUs with an efficiency rate of 1 form the efficiency frontier that envelops inefficient units. This means that - for each decision-making problem - there is a set of production possibilities comprising all feasible input-output combinations. This set is surrounded by the efficiency frontier, which shows the highest level of outputs that can be achieved with a given amount of inputs. For the DEA method, returns to scale play an important role. In the case of constant economies of scale (CCR models), the efficiency frontier is a straight line. For the BCC model with variable returns to scale, the efficiency frontier has a convex shape. Models can be either input or output oriented. An input-oriented model assumes constant outputs. This means that in order to maximise efficiency, inputs need to be adjusted. An output-oriented model assumes constant inputs and aims to maximise outputs. 


\section{Literature Review}

At present, competing firms have a very strong tendency to agglomerate or group if they are located in a particular close geographic area (Akhmetshin et al., 2017; Alcácer and Chung 2014; Krugman 1991; Krugman 2010). The concept of clusters is linked to various conceptual and theoretical approaches around locally embedded groups of firms and other organisations, such as industrial districts or regional innovation systems (Uyarra and Ramlogan 2012). Porter's theory of clusters has sparked debate across a range of academic disciplines: from spatial planning and economic geography to public administration and economic development (Motoyama 2008). The past two decades have witnessed a great wave of interest in clusters by experts and economic policy makers, and support for clusters has become the predominant strategy to support regional development (Fang 2015). Clusters have now become a modern form of industrial cooperation, and the innovative nature of clusters is considered one of the key sources of a regional and national competitive advantage (D'Alise et al. 2014; Vasiljeva, 2013b).

Literature provides many definitions of a cluster: Porter (1998) defines a cluster as a geographically proximate group of interconnected companies and associated institutions in a particular field, linked by commonalities and complementarities. The OECD (2002) defines a cluster as a network of strongly interdependent firms, knowledgeproducing agents (e.g. universities, research institutes), bridging institutions (e.g. brokers, consultants) and customers linked to each other in the production chain. Enright (1996) defines a cluster as a regional grouping in which member firms are in close proximity to each other. According to Swann and Prevezer (1998), clusters are large groups of firms in related industries and operating in a particular location. Ketels and Memedovic (2008) view clusters as the natural manifestation of expertise, skills, and infrastructure in improving productivity as a key determinant for maintaining a high level of prosperity in a given location. The above definitions of a cluster have one thing in common: the geographical concentration of firms and other institutions in a particular industry and a particular region. Such clusters can be described as being natural. In addition, clusters are currently being used as a regional-policy tool. Such clusters are the result of the organised efforts of a certain institution's cluster initiative (Sölvell et al. 2003). The result is the establishment of a cluster organisation as a legal entity that brings together enterprises, universities, research and professional institutions, and other entities for a particular purpose, for example in order to implement joint projects, share research infrastructure, and achieve cost savings. The present research assesses both types of clusters - natural clusters and cluster organisations - in order to determine whether the cluster type has an effect on the innovation performance of enterprises.

According to De Propris and Driffield (2006), cluster firms are characterised by a high degree of specialisation and complementarity. The benefits of clustering are very important in connection with innovations, technological changes, and the amount of spending on research and development (Ferreira et al. 2012). Porter (1998) notes that competition among cluster firms forces firms to increasingly innovate, improve, and create new technologies. According to Kaličanin and Gavrić (2014), clusters support the firms' productivity and innovation capabilities because these groups of firms have an information database that they can fully use.

In professional literature, it is widely acknowledged that the absorption capacity of firms to identify, acquire, understand, and use external knowledge directly affects their innovation capacity and performance (Terstriep and Lüthje 2012). At present, industrial groupings are considered one of the most important paths to open innovation and economic excellence (Zhao et al. 2010).

A firm's ability to innovate is not limited solely by the firm's boundaries, but it is increasingly dependent on external resources that exist in certain locations. Cluster membership should benefit a firm in terms of its innovation output rather than in terms of the firm's financial or growth performance (Lecocq et al. 2011). 
There are many studies that deal with spatial concentration and its contribution to a dynamic agglomeration economy. Earlier studies on the dissemination of knowledge and innovations within clusters came to the conclusion that spatial proximity alone brings innovations (Baptista 2000; Feldman 1999; Audretsch and Feldman 1996). However, recent studies have shown that spatial proximity must be coupled with cultural, cognitive, or organisational proximity to stimulate interactive learning and innovations (Terstriep and Lüthje 2012; Razminienè, Tvaronavičienè 2017; Suleimanova, 2014).

Many researchers have addressed the question of whether firms in clusters are more or less innovative than nonclustered firms. There are a number of empirical studies that prove that enterprises in a cluster may have a greater tendency towards innovation. However, the innovativeness of a cluster as a whole remains questionable, especially because it is difficult to measure (Zhao et al. 2010). For example, in their research on the Pakistanbased Faisalabad textile cluster, Khan and Gani (2004) argue against the cluster's importance and role in facilitating technological innovation and entrepreneurship.

In their article, Gimeno and Beal (2001) attempt to verify three hypotheses: 1) whether a geographical agglomeration affects a group of firms' involvement in innovation activities; 2) whether an agglomeration affects the group of firms' ability to successfully innovate; and 3) whether agglomerations affect firms' performance on the market. These questions were tested using a sample of 56 firms in the software industry in 1982 and 1998. Gimeno and Beal (2001) argue that the advantages of an agglomeration or clustering diminish over time, and even reduce the member firms' motivation to engage in innovation activities.

Audretsch and Feldman (1996) examined a database consisting of 8,074 commercial innovations that were introduced in the US in 1982. The research showed that that year, the vast majority of these innovations were created in firms headquartered either on the east or west coast. One possible explanation for this phenomenon is that the concentration of industry is associated with research and development activities. The authors also came to the conclusion that clustering mainly occurs in industries where there is university research, internal research and development, and a skilled labour force.

Other authors focus on patent citations. Jaffe et al. (1993) examine the connection between localisation and patent citations. Patent applications include quotations and references to previous patents. Research that was conducted in 1975 and 1980 and that examined more than 10,000 citations shows that patents tend to reference previous patents granted to firms in the same region.

Baptista and Swann (1998) analysed innovations that had been implemented by 248 British manufacturing firms in 1975 and 1982 and their article compared clustered firms with non-clustered firms. They found that strong industrial employment in a specific region increases the likelihood that the firm will innovate.

Based on data from Great Britain and Italy, Beaudry and Breschi (2003) found that clustering alone did not lead to higher innovation performance. Using European patent data as an indicator of enterprises' innovation activities, they conclude that the benefits of clustering arise only in clusters that are densely populated by innovative firms and have a large accumulated share of knowledge.

It is clear from the above that the empirical results are not consistent. Terstriep and Lüthje (2012) propose the hypothesis that interaction intensity within a cluster and innovation initiative are positively linked to the member firms' innovation performance. In their article, they presented the results of a survey responded to by managers of 107 firms in two regional ICT clusters in Germany and Switzerland. The findings show that the inclusion of firms in a cluster significantly increases their innovation success, which has a positive impact on their overall performance. 
However, innovation success often depends on specific conditions. For example, an analysis of financial performance that was carried out on firms in the semiconductor and pharmaceutical industries did not reveal any significant differences in performance between clustered and non-clustered firms at the beginning of their life cycle, while in later phases, non-clustered firms outperformed clustered firms (Kukalis 2010). Also, research by Žižka (2017) revealed the effect of the duration of the cluster's existence on performance. It addressed the effect of a textile cluster on the financial performance of member organisations. Financial performance was assessed using economic added value. It was found that the efficiency of firms in the cluster increased over the 5-year period under review, both due to a technological shift of the efficiency frontier and due to an improvement in internal efficiency resulting from economies of scale.

The results of a comparative analysis of biotech firms in the US, Israel, Sweden, India, and Great Britain by Folta et al. (2006) essentially support the existence of a positive cluster effect on member firms' innovativeness. The study also reveals that this effect decreases or even disappears in proportion to cluster size. A study of two information and communication clusters in Germany and China (Zhao et al. 2010) shows that especially soft factors (such as the network mechanism of the cluster) have a positive effect on the innovation performance of firms.

However, some experts (Fang 2015) warn that clusters may also inhibit innovation (negative externalities, excessive competition, and knowledge leakage). Nonetheless, many empirical studies reveal a rather positive relationship between clusters and innovation. In an article, Fang (2015) performed a meta-analysis of empirical studies on the relationships between clusters and innovations since the 1980s. The results show that clusters have a positive effect on innovation. At the same time, it must be noted that this positive relationship is not automatic and may be limited to a certain number of industries, certain development phases, certain locations, and certain specific conditions (Uyarra and Ramlogan 2012). The effect of the various industries on innovation performance was addressed by Žižka et al. (2016). The research assessed the performance of Czech innovative enterprises in 15 different industries using a two-stage DEA method. In the first stage, they measured the enterprises' ability to use available resources to generate the results of technical creative activities and subsequently the ability to commercialise the results. They came to the conclusion that innovation performance depends on the industry. In both components, it was found that the automotive industry had the largest proportion of successful firms, while the chemical industry had the smallest proportion. The research presented in this paper attempts to reveal whether cluster organisations that are set up to boost innovation have any effect on the innovation performance of enterprises.

\section{Methodology}

The research is based on the use of a two-stage Data Envelopment Analysis model that assumes variable returns to scale and is input-oriented. The research process can be divided into the following steps:

Step 1: Compiling a list of enterprises to be assessed in both industries - information on the members of the CLUTEX and NANOPROGRESS cluster organisations was sourced from both clusters' websites as of 31 December 2017. As of that date, the CLUTEX technical textiles cluster had 29 members, and the NANOPROGRESS cluster had 38 members. For each member, an analysis of its scope of business was performed according to the NACE statistical classification. In the case of the textile cluster, the core of the cluster consists of enterprises in industries NACE 132, 139, and 141. For the nanotechnology cluster, it is activity NACE 721. In the next stage, the regional coverage of both clusters was determined using localisation coefficients, see equation (1), taking into account the place of business of the members of both cluster organisations. In total, 4 samples were created: 2 for members of a cluster organisation (CLUTEX, NANOPROGRESS) and 2 for natural 
clusters. Each entity could only be a member of one sample, i.e. if it is a member of a cluster organisation, it is only assessed within that cluster organisation and not within the natural cluster.

$$
L Q_{i}=\frac{\frac{E_{\text {ir }}}{E_{r}}}{\frac{E_{\text {in }}}{E_{n}}}
$$

where $L Q_{i}$ is the localisation coefficient in industry $i, E_{\text {in }}$ is the number of employees in industry $i$ at the national level, $E_{i r}$ is the number of employees in industry $i$ in region $r, E_{n}$ is the number of employees at the national level, and $E_{r}$ is the number of employees in region $r$.

Since CZSO's statistical yearbooks only cite employee figures with an accuracy of two-digit NACE codes, the MagnusWeb database of data on enterprises (Bisnode, 2017) was used to determine the number of employees in the different industries.

Textile and apparel manufacturing industries NACE 132, 139, and 141 (Weaving of textiles, Manufacture of other textiles, Manufacture of worn apparel, except fur apparel) are mainly concentrated in the Hradec Králové Region and the Pardubice Region, with an overlap into the Liberec Region, i.e. in the Northeast Cohesion Region. These are also the regions in which most members of the CLUTEX technical cluster operate. In addition, textile and apparel manufacturing also has a relatively important position in the Karlovy Vary Region and the South Moravian Region which, however, do not form one geographical unit with the Northeast region. Therefore, the Northeast region was defined as the natural textile cluster. Within this area, there were 164 enterprises operating in the above industries (excluding members of the CLUTEX cluster organisation, which formed a separate research sample).

Industry 721 Research and experimental development on natural sciences and engineering is mainly located in Prague and the neighbouring Central Bohemian Region and Pardubice Region (see Table 1). The relatively high concentration of this industry in the South Bohemian Region results from the Biological Institute of the Czech Academy of Sciences being located there, but the scope of its activities differs from the focus of a nanotechnology cluster. Apart from this one institution, no other major enterprises from the industry operate in the South Bohemian Region. Therefore, it can be concluded that the natural nanotechnology cluster includes the areas of three regions - Prague, the Central Bohemian Region, and the Pardubice Region. Within this area, there were 499 entities operating in industry 721 (excluding members of the NANOPROGRESS cluster organisation, which forms a separate research sample).

Step 2: Defining inputs and outputs - in the first phase, the enterprise's ability to use sources to create industrial property rights was assessed (see Figure 1). Employee numbers, long-term capital (equity, long-term liabilities, and long-term bank loans) and the duration of the firm's existence (which can be understood as a certain form of accumulated intellectual capital) were used as sources. The data were obtained from the MagnusWeb database (Bisnode 2017), and accounting data originated from balance sheets and profit and loss statements. The MagnusWeb database borrows financial statements from the collection of documents of the Commercial Register. Unfortunately, it must be noted that although firms have a statutory obligation to publish financial statements, many firms fail to meet this obligation and do not publish data in the Commercial Register. In the case of the CLUTEX cluster organisation, financial statements for 2015 were successfully obtained for 25 entities, and for 32 entities the NANOPROGRESS cluster. For the natural clusters, 100 financial statements were obtained for the textile cluster and 89 financial statements for the nanotechnology cluster. For 2016, the numbers of available financial statements were significantly lower. Therefore, data for 2015 were used. 
Table 1. Localisation coefficients by industry

\begin{tabular}{|l|c|c|}
\hline Region & NACE 132+139+141 & NACE 721 \\
\hline Prague & 0.41 & $\mathbf{3 . 6 3}$ \\
\hline Pardubice & $\mathbf{3 . 9 7}$ & $\mathbf{1 . 0 6}$ \\
\hline South Moravian & $\mathbf{1 . 1 9}$ & 0.72 \\
\hline Central Bohemia & 0.16 & $\mathbf{1 . 2 8}$ \\
\hline Liberec & $\mathbf{1 . 5 9}$ & 0.26 \\
\hline Plzeň & 0.34 & 0.41 \\
\hline South Bohemian & $\mathbf{1 . 0 7}$ & $\mathbf{2 . 3 4}$ \\
\hline Karlovy Vary & $\mathbf{1 . 5 9}$ & 0.08 \\
\hline Vysočina & 0.99 & 0.08 \\
\hline Olomouc & 0.52 & 0.12 \\
\hline Zlín & 0.11 & 0.19 \\
\hline Hradec Králové & $\mathbf{4 . 5 5}$ & 0.32 \\
\hline Moravian-Silesian & 0.32 & 0.13 \\
\hline Ústí nad Labem & 0.65 & 0.11 \\
\hline
\end{tabular}

Source: MagnusWeb, 2017; Authors' calculations

The output of the first model is the number of patents, including European patents, utility models, industrial designs, and trademarks. The data were obtained through a search in the databases of the Industrial Property Office in January 2018. The numbers of active industrial property rights were sought.

In the second phase, to what degree enterprises were able to commercialise the protected results of technical creative activity was assessed. Since the DEA method requires inputs and outputs of the models to be nonnegative, an indicator measuring enterprises' revenues against costs was constructed as the output. This is because a number of enterprises reported a loss and a negative value was added. For profit-making enterprises, the value of the indicator is greater than one, whereas for loss-making enterprises it is less than one, but it is always nonnegative.

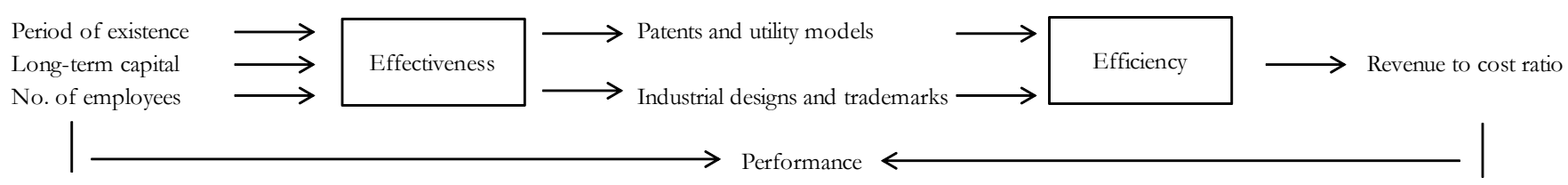

Fig. 1. Inputs and outputs of the model Source: Prepared by the authors

Step 3: Formulating the mathematical model - based on previous studies (Žižka et al. 2016) that found increasing or decreasing returns to scale, the BCC model was used. It assumes variable returns to scale and is input oriented. The model's solution aims to minimise the purpose function $z$ (2) under restrictive conditions (3), see e.g. Jablonský and Dlouhý (2004). Inputs are indicated as the symbols $x_{i}$, their weights as $v_{j}$, outputs are $y_{i}$ with weights $u_{i}$. The variable $\mu$ is the deviation from constant returns to scale. The model was solved using the OSDEA-GUI open software (Virtos 2016).

$$
\mathrm{z}=\sum_{i=1}^{r} u_{i} y_{i q}+\mu
$$




$$
\begin{aligned}
& \sum_{i=1}^{r} u_{i} y_{i k}+\mu \leq \sum_{j=1}^{m} v_{j} x_{j k}, k=1,2, \ldots, n \\
& \sum_{j=1}^{m} v_{j} x_{j q}=1 \\
& u_{i} \geq \varepsilon, i=1,2, \ldots r, \varepsilon \text { - very small non- Archimedea n number }(>0) \\
& v_{j} \geq \varepsilon, j=1,2, \ldots, m, \\
& \mu \in R
\end{aligned}
$$

Step 4: Determining the effectiveness, efficiency, and performance scores - based on solutions to DEA models, the effectiveness, efficiency, and performance scores were determined for all four research samples, namely first for each entity and then for the entire research sample (i.e. for both cluster organisations - CLUTEX and NANOPROGRESS and for both natural clusters). For each sample, average values for the effectiveness, efficiency, and performance scores, standard deviations, and medians were calculated.

Step 5: Comparing the effectiveness, efficiency, and performance scores - the average and median values of effectiveness, efficiency, and performance for each research sample were compared. The basic research assumption was that enterprises in a cluster organisation show higher innovation performance than enterprises operating outside the cluster organisation. Secondly, it was assumed that enterprises in a high-tech industry would have better innovation performance than enterprises in a traditional industry. These basic research assumptions were operationalised into the following hypotheses:

H1: Members of the CLUTEX cluster organisation show a higher degree of innovation effectiveness than enterprises in the natural textile cluster.

$\mathrm{H} 2$ : Members of the CLUTEX cluster organisation have a higher degree of efficiency in commercialising industrial property rights than enterprises outside the cluster organisation.

H3: The overall innovation performance of member entities in the CLUTEX cluster organisation is higher than that for enterprises operating independently outside the cluster organisation.

H4: Members of the NANOPROGRESS cluster organisation achieve higher innovation effectiveness scores than independent enterprises operating in the same industry and regions.

H5: Members of the NANOPROGRESS cluster organisation achieve higher efficiency in commercialising industrial property rights compared to non-member entities.

H6: The overall innovation performance of members of the NANOPROGRESS cluster organisation is higher than that for enterprises operating independently outside the cluster organisation.

H7: Innovation effectiveness in the NANOPROGRESS cluster organisation is higher than that for the CLUTEX cluster organisation.

H8: The efficiency of industrial property rights commercialisation in the NANOPROGRESS cluster organisation is higher compared to the CLUTEX cluster organisation.

H9: The overall innovation performance of the NANOPROGRESS cluster organisation is higher than that for the CLUTEX cluster organisation.

H10: Innovation effectiveness is higher for enterprises in the natural nanotechnology cluster compared to enterprises in the natural textile cluster.

H11: The efficiency of industrial property rights commercialisation is also higher for enterprises in the natural nanotechnology than that for enterprises in the natural textile cluster.

H12: Overall innovation performance is higher in the natural nanotechnology cluster compared to the natural textile cluster. 
In order to test the above hypotheses, it was necessary to obtain information on whether all data were normally distributed. The normality of all data samples was tested using the Shapiro-Wilk test, where the null hypothesis assumes that the sample comes from a normally distributed population. All tests that were used to obtain the outputs presented in this paper were performed at a 5\% significance level, i.e. including normality tests. It turned out that none of the twelve samples was normally distributed. Where data were not normally distributed, this may have been due to the nature of the data or due to the presence of outliers. For each data sample, the Dean-Dixon Q test was therefore also used to verify whether the sample contained outliers. It was found that none of the samples contained any outliers.

Based on the results of the two previous methods, the authors decided to use the Mann-Whitney U test to compare the above indicators in two selected samples (as described in hypotheses 1-12). This test should be used to compare the expected values (most commonly the medians) in two independent samples where the data are not normally distributed.

\section{Empirical Results and Discussion}

The research results are divided into two parts. In the first part, the average effectiveness, efficiency, and performance scores were analysed in each research sample. In the second part, the differences between cluster organisations and industries were assessed.

\subsection{Innovation effectiveness, efficiency, and performance}

For each enterprise and subsequently for each research sample, the innovation effectiveness score, the score of industrial property rights commercialisation efficiency, and the overall innovation performance score were determined. Table 2 shows that the average innovation effectiveness score ranged from 0.57 to 0.77 . This means that, on average, enterprises would have to reduce their inputs by $23 \%$ to $43 \%$ in order for us to consider the use of inputs as being effective to protect the results of technical creative activity and to protect rights to marks. Nine enterprises (36\%) in the CLUTEX cluster organisation and 12 enterprises (12\%) in the natural textile cluster were located on the efficiency frontier. In the other industry, namely nanotechnology, 10 enterprises $(31.25 \%)$ in the NANOPROGRESS cluster organisation and 18 enterprises $(20.22 \%)$ in the natural cluster were located on the efficiency frontier. In other words, this means that enterprises tend to underestimate the issue of industrial property rights protection. In the next phase, the ability of enterprises to commercialise registered industrial property rights (i.e. to turn them into profits) was examined. In all of the samples under examination, the average efficiency score was relatively low - ranging from 0.41 to 0.63 . This means that in economic terms, enterprises are not able to adequately capitalise on their registered industrial property rights. In order to achieve full efficiency, a $37 \%$ to $59 \%$ smaller amount of registered industrial property rights would suffice. In the second phase of the analysis, 6 enterprises (24\%) in the CLUTEX cluster organisation and 10 enterprises (31.25\%) in the NANOPROGRESS cluster organisation were located on the efficiency frontier. In the natural clusters, only 7 enterprises $(7 \%)$ in the textile industry and 5 enterprises $(5.62 \%)$ in the nanotechnology industry were located on the efficiency frontier. The overall innovation performance was obtained as the product of the innovation effectiveness score multiplied by the innovation efficiency score.

\subsection{A comparison of the differences between industries}

In the next part of the research, the significance of the differences in innovation effectiveness, efficiency, and performance both between cluster organisations and between enterprises operating independently outside cluster organisations was analysed in both industries. The test results are clearly shown in Table 3. 
Table 2. Average effectiveness, efficiency, and performance scores.

\begin{tabular}{|l|c|c|c|c|}
\hline \multirow{2}{*}{\multicolumn{1}{|c|}{ Indicator }} & \multicolumn{4}{c|}{ Cluster } \\
\cline { 2 - 5 } & CLUTEX & Textile natural & NANOPROGRESS & Nano natural \\
\hline Effectiveness - average & 0.6908 & 0.5703 & 0.6692 & 0.7692 \\
\hline Effectiveness - SD & 0.2638 & 0.2715 & 0.2431 & 0.2267 \\
\hline Effectiveness - median & 0.6308 & 0.4811 & 0.5241 & 0.8057 \\
\hline Efficiency - average & 0.5650 & 0.4050 & 0.6343 & 0.5311 \\
\hline Efficiency - SD & 0.2734 & 0.3123 & 0.2897 & 0.3280 \\
\hline Efficiency - median & 0.4942 & 0.2307 & 0.5626 & 0.5000 \\
\hline Performance - average & 0.4367 & 0.2996 & 0.4685 & 0.4626 \\
\hline Performance - SD & 0.3381 & 0.3474 & 0.3424 & 0.3551 \\
\hline Performance - median & 0.3171 & 0.1158 & 0.2753 & 0.4267 \\
\hline
\end{tabular}

Source: Authors' calculations

Table 3. A comparison of effectiveness, efficiency, and performance in both industries.

\begin{tabular}{|l|c|c|}
\hline Hypothesis & P-Value & Conclusion \\
\hline H1 & 0.01763 & H1 was proven. \\
\hline H2 & 0.001040 & H2 was proven. \\
\hline H3 & 0.001232 & H3 was proven. \\
\hline H4 & $\begin{array}{c}0.9684 \\
(0.03158)\end{array}$ & $\begin{array}{c}\text { H4 was not proven. } \\
\text { (The opposite was proven. })\end{array}$ \\
\hline H5 & 0.04282 & H5 was proven. \\
\hline H6 & 0.3525 & $\begin{array}{c}\text { H6 was not proven. } \\
\left(\mathrm{H}_{0} \text { is not rejected for any alternative hypothesis. }\right)\end{array}$ \\
\hline H7 & $\begin{array}{c}\text { H7 was not proven. } \\
\left(\mathrm{H}_{0} \text { is not rejected for any alternative hypothesis. }\right)\end{array}$ \\
\hline H8 & 0.6315 & $\begin{array}{c}\text { H8 was not proven. } \\
\left(\mathrm{H}_{0} \text { is not rejected for any alternative hypothesis. }\right)\end{array}$ \\
\hline H9 & 0.1966 & $\begin{array}{c}\text { H9 was not proven. } \\
\left(\mathrm{H}_{0} \text { is not rejected for any alternative hypothesis. }\right)\end{array}$ \\
\hline H10 & 0.4421 & H10 was proven. \\
\hline H11 & $1.7565 \cdot 10^{-7}$ & H11 was proven. \\
\hline H12 & 0.005121 & H12 was proven. \\
\hline
\end{tabular}

Source: Authors' calculations

This table 3 points to the establishment of the CLUTEX cluster organisation as having had a positive effect on the innovation performance of its member enterprises, i.e. both its components. This means that member entities of the CLUTEX cluster show a better ability to use resources to create industrial property rights while also being able to commercialise them more effectively, which is reflected in their better economic performance compared to enterprises that are not part of a cluster organisation. This - in turn - underlies the superior innovation performance of the members of the CLUTEX cluster organisation. The result of the third test is logically predictable given the nature of the data - the performance indicator is the product of the efficiency indicator multiplied by the effectiveness indicator. 
Focusing on the area of nanotechnology, the fourth hypothesis aims to prove that members of the NANOPROGRESS cluster organisation achieve higher innovation effectiveness scores than enterprises in the natural nanotechnology cluster. However, in this case, the assumption that the cluster organisation has a positive effect on innovation activities was not proven. Looking at the high p-value (0.9684; see Table 3$)$, the details of the test were examined in order to identify the reasons for such a high value. It was found that the median value was 0.5241 in the first sample (i.e. the NANOPROGRESS cluster organisation) and 0.8057 in the second sample (containing data for the natural nanotechnology cluster). Even these sampling values already indicate that the right-tailed hypothesis cannot be proved. However, if an alternative left-tailed hypothesis is defined, we obtain a p-value of 0.0316 , which means that it is possible to prove the opposite of the original assumption at a 5\% significance level. This means that enterprises in a natural nanotechnology cluster have a higher innovation effectiveness score than the members of the NANOPROGRESS cluster organisation.

In the next step (H5), we examined whether enterprises that were organised in the NANOPROGRESS cluster were able to achieve a higher efficiency of industrial property rights commercialisation compared to the natural nanotechnology cluster. In this case, it is possible to prove that the cluster organisation has a positive effect on industrial property rights commercialisation and economic results. However, it was not proven (H6) that the overall innovation performance of the member organisations of NANOPROGRESS is higher. In the case of NANOPROGRESS, the cluster organisation only had a partial effect on innovation performance.

In the next three tests (H7 to H9), the two cluster organisations - CLUTEX and NANOPROGRESS - were compared. First, the assumption that innovation effectiveness in the NANOPROGRESS cluster organisation is higher than that for the CLUTEX organisation was tested. However, this hypothesis was not proven. The hypothesis that the NANOPROGRESS cluster organisation had a higher efficiency of industrial property rights commercialisation also was not proven. Logically, the overall innovation performance of the members of the NANOPROGRESS cluster organisation is thus not higher than for the cluster organisation in the textile industry. Within the last group of three assumptions, the first claim to be assessed was that enterprises in the natural nanotechnology cluster have a higher innovation effectiveness than in the natural textile cluster (H10). This hypothesis was proven. Also, industrial property rights commercialisation was identified to be more effective in the nanotechnology industry (H11) and, logically, the overall innovation performance of enterprises in this industry was found to be higher compared to the textile industry (H12).

The results of the research show that the establishment of the CLUTEX cluster organisation has had a positive effect on the innovation activities of its member enterprises. The textile industry is one of the Czech Republic's most traditional industries. At the same time, this industry has undergone a major transformation over the past 25 or so years. Conventional mass textile production has all but disappeared from the Czech Republic due to competition from cheap Asian production. Over the 1993-2015 period, the number of employees in textile manufacturing decreased by two-thirds (CZSO 1993; CZSO 2017). However, the industry still employs more than 50,000 people. Enterprises that were able to overcome the crisis in the industry had to reorient themselves towards products with high value added such as technical textiles, textiles for the health sector, sports uses (artificial lawns), and so on. The CLUTEX cluster organisation brings together key players in the industry, including its research base. For enterprises in the textile industry, the establishment of a cluster organisation was probably the key factor that strengthened their innovation activities and competitiveness on the market.

By contrast, in the nanotechnology industry, the cluster organisation was not proven to have a positive effect on generating industrial property rights. This may be due to the fact that nanotechnology enterprises are very innovative, regardless of whether or not they are members of a cluster organisation. The positive effect of the NANOPROGRESS cluster organisation could then be seen in the members' better ability to commercialise 
industrial property rights and, by extension, achieve better economic results. Nevertheless, even this partial benefit of the cluster organisation can be assessed as positive.

For textile enterprises, the importance of being organised in a cluster was confirmed by the fact that innovation effectiveness and commercialisation were significantly higher for non-clustered firms in the nanotechnology industry than for non-clustered firms in the textile industry. However, in the case of the member enterprises of the two cluster organisations, there are no significant differences in innovation performance. This means that enterprises in the textile industry that had joined the CLUTEX cluster organisation were able to catch up with enterprises in the NANOPROGRESS cluster organisation in terms of generating industrial property rights and being able to commercialise them, as well as in terms of overall innovation performance.

In principle, the results of the research confirm the findings presented in literature, namely that clusters have a positive effect on the innovation activities of enterprises (Ferreira et al. 2012; Porter 1998, Kaličanin and Gavrić 2014; Babtista 2000). However, it turns out that the specific conditions of the various industries play an important role. While in the textile industry, the formation of a cluster organisation was proven to have a clearly positive effect on the innovation performance of its member enterprises, only a weak effect was found in the other industry, nanotechnology. This finding is consistent with the findings (Uyarra and Ramlogan 2012) that the positive correlation between clusters and innovation is not automatic. The fact that a weaker effect was found in a modern technology industry is somewhat analogous to studies from the software industry (Isaksen 2006) and the biotechnology industry (Folta et al. 2006), which arrived at similar conclusions.

\section{Conclusions}

This research aimed to determine whether cluster organisations had a significant effect on the innovation activities of its member entities. A clearly positive effect of cluster organisation membership was proven in the technical textiles industry. Member enterprises of the CLUTEX cluster organisation behave more effectively in generating industrial property rights and are able to commercialise them more effectively than other enterprises in the textile industry operating in the same region. As a result, their innovation performance is higher. By contrast, the same effect was not proven in the nanotechnology industry. The cluster organisation was only found to have a positive effect on industrial property rights commercialisation. However, the innovation performance of member enterprises in the NANOPROGRESS cluster organisation was not higher than for non-clustered firms. A stronger effect of clustering on innovation performance was thus proven in the traditional textile and apparel manufacturing industry. Enterprises in both cluster organisations showed basically no differences in their innovation performance level. This indicates that the formation of a cluster organisation has a significant effect on achieving higher innovation performance in traditional industries. For firms in the textile industry, cluster membership is an important factor in their competitiveness.

The research results show that the effect of cluster organisations on innovation activities depends on the industry. Contrary to initial expectations, in the case under review, a stronger effect proved to exist in a traditional industry than in the high-tech sector. However, the research was only based on data from two industries, which must be considered a limiting factor. Therefore, follow-up research will focus on verifying the effect of the industry on innovation performance in clustered versus non-clustered enterprises. The research samples will include a mix of various industries in which cluster organisations exist. 


\section{References}

Akhmetshin, E. M.; Kolpak, E. P.; Sulimova, E. A.; Kireev, V. S.; Samarina, E. A.; Solodilova, N. Z. 2017. Clustering as a criterion for the success of modern industrial enterprises, International Journal of Applied Business and Economic Research 15(23): 221-231. https://www.scopus.com/inward/record.uri?eid=2-s2.0-85038933529\&partnerID=40\&md5=040e9b285096f5293596e2ac050d4bdb

Alcácer, J.; Chung, W. 2014. Location Strategies for Agglomeration Economies, Strategic Management Journal 35(12): 1749-1761. http://doi.org/10.1002/smj.2186

Audretsch, D. B.; Feldman, M. P. 1996. R\&D spillovers and the geography of innovation and production, The American Economic Review 86(3): 630-640.

Baptista, R. 2000. Do innovations diffuse faster within geographical clusters? International Journal of Industrial Organization 18(3): 515535. http://doi.org/10.1016/S0167-7187(99)00045-4

Baptista, R.; Swann, P. 1998. Do firms in clusters innovate more? Research Policy 27(5): 525-540. http://doi.org/10.1016/S0048$\underline{7333(98) 00065-1}$

Beaudry, C.; Breschi, S. 2003. Are firms in clusters really more innovative? Economics of Innovation and New Technology 12(4): 325342. http://doi.org/10.1080/10438590290020197

Bisnode. 2017. MagnusWeb CZ Database. Available on the Internet: https://magnusweb.bisnode.cz

CzechInvest. 2018. Statistika čerpání dotaci a zvýhodněných úvěrů z programů OPPP [Statistics on the use of subsidies and preferential credits from OPIE programs]. Available on the Internet: http://isop.czechinvest.org/isop_oppp/WebVystupy/stat_cerp_dotaci_z_OPPP.aspx

CZSO. 1993. Statistical Yerbook of the Czech Republic 1993. Prague: Czech Statistical Office.

CZSO. 2017. Statistical Yearbook of the Czech Republic 2017. Prague: Czech Statistical Office. Available on the Internet: https://www.czso.cz/csu/czso/statistical-yearbook-of-the-czech-republic

D'Alise, C.; Giustiniano, L.; Peruffo, E. 2014. Innovating Through Clusters, International Journal of Engineering Business Management 6(28): 1-14. http://doi.org/10.5772/59028

De Propris, L.; Driffield, N. 2006. The importance of clusters for spillovers from foreign direct investment and technology sourcing, Cambridge Journal of Economics 30(2): 277-291. http://doi.org/10.1093/cje/bei059

Enright, M. J. 1996. Regional Clusters and Economic Development: A Research Agenda, in Staber, U. H. (Ed.); Schaefer, N. V. (Ed.); Sharma, B. D. (Ed.). Business Networks: Prospects for Regional Development. Berlin: de Gruyter, 190-214.

Fang, L. 2015. Do Clusters Encourage Innovation? A Meta-analysis, Journal of Planning Literature 30(3): 239-260. http://doi.org/10.1177/0885412215589848

Feldman, M. P. 1999. The New Economics Of Innovation, Spillovers And Agglomeration: A review Of Empirical Studies, Economics of Innovation and New Technology 8(1-2): 5-25. http://doi.org/10.1080/10438599900000002

Ferreira, M. P.; Serra, F. R.; Costa, B. K.; Maccari, E. A.; Couto, H. R. 2012. Impact of the Types of Clusters on the Innovation Output and the Appropriation of Rents from Innovation, Journal of Technology Management and Innovation 7(4): 70-80.

Folta, T. B.; Cooper, A. C.; Baik, Y. 2006. Geographic cluster size and firm performance, Journal of Business Venturing 21(2): 217-242. http://doi.org/10.1016/j.jbusvent.2005.04.005

Gimeno, J.; Beal, B. D. 2001. Geographical Agglomeration, Knowledge Spillovers, and Competitive Evolution. Academy of Management Annual Meeting Proceedings, No. 1. Ed. by Guclu, A., August 2001, New York: Academy of Management, A1-A6. http://doi.org/10.5465/APBPP.2001.6123142

Isaksen, A. 2006. Knowledge-intensive industries and regional development: The case of software industry in Norway, in Cooke, P. (Ed.); Piccaluga, A. (Ed.). Regional Development in the Knowledge Economy. London, New York: Routledge, 43-62. 
Jaffe, A. B.; Trajtenberg, M.; Henderson, R. 1993. Geographic localization of knowledge spillovers as evidenced by patent citations, The Quarterly Journal of Economics 108(3): 577-598. http://doi.org/10.2307/2118401

Jablonský, J.; Dlouhý, M. 2004. Modely hodnoceni efektivnosti produkčnich jednotek [Models of Efficiency Assessment for DecisionMaking Units]. Prague: Professional Publishing.

Kaličanin, D.; Gavrić, O. 2014. The importance of clusters as drivers of competitive advantage of companies, Ekonomika preduzeća 62(34), 164-172.

Ketels, C. H. M.; Memedovic, O. 2008. From clusters to cluster-based economic development, International Journal of Technological Learning, Innovation and Development 1(3): 375-392.

Khan, J. H.; Ghani, J. 2004. Clusters and Entrepreneurship: Implications for Innovation in a Developing Economy, Journal of Developmental Entrepreneurship 9(3): 221-238.

Krugman, P. 1991. Increasing Returns and Economic Geography, The Journal of Political Economy 99(3): 483-499.

Krugman, P. 2010. The new economic geography, Now middle aged, Regional Studies 45(1): 1-7, http://doi.org/10.1080/00343404.2011.537127

Kukalis, S. 2010. Agglomeration Economies and Firm Performance: The Case of Industry Clusters, Journal of Management 36(2), 453481. http://doi.org/0.1177/0149206308329964

Lecocq, C.; Leten, B.; Kusters, J.; van Looy, B. 2011. Do Firms Benefit from being Present in Multiple Technology Clusters? An Assessment of the Technological Performance of Biopharmaceutical Firms, Regional Studies 46(9): 1107-1119. http://doi.org/10.1080/00343404.2011.552494

Motoyama, Y. 2008. What Was New About the Cluster Theory? Economic Development Quarterly 22(4): 353-363.

OECD. 2002. OECD Science, Technology and Industry Outlook. Paris: OECD.

Porter, M. E. 1998. Clusters and the New Economics of Competition, Harvard Business Review 76(6): 77-90.

Razminienè, K.; Tvaronavičienè, M. 2017. Economic globalization and its impacts on clustering, Terra Economicus 15 (2): $109-121$. http://doi.org/10.23683/2073-6606-2017-15-2-109-121

Sölvell, Ö.; Lindqvist, G.; Ketels, Ch. 2003. The Cluster Initiative Greenbook. Stockholm: VINNOVA.

Suleimanova, K.A. 2014. Trends in the development of the world exhibition industry. Mechanization of construction 6 (840): 57-59.

Swann, G.; Prevezer, M. 1998. A comparison of the dynamics of industrial clustering in computing and biotechnology, Research Policy 25, $1139-1157$.

Terstriep, J.; Lüthje, C. 2012. Do clusters as open innovation systems enhance firms' innovation performance? 19th International Product Development Management Conference: "Transformative Research in Product and Service Innovation". June 17-19, Manchester, UK. Manchester: Manchester Business School, 1-36. Available on the Internet: http://tips-nrw.iatge.de/aktuell/veroeff/2012/terst01.pdf

Uyarra, E.; Ramlogan, R. 2012. The effects of cluster policy on innovation. Nesta Working Paper No. 12/05. Available on the Internet: https://www.nesta.org.uk/sites/default/files/the_effects_of_cluster_policy_on_innovation.pdf

Vasiljeva, M.V. 2013a. Directions of improvement of cluster policy. Contemporary Economic Issues 4. 10.24194/41311

Vasiljeva, M.V. 2013b. The role of innovative clusters in the process of internationalization of firms. Contemporary Economic Issues 3. $\underline{10.24194 / 31309}$

Virtos, H. 2016. Open Source DEA Software. Available on the Internet: http://opensourcedea.org 
The International Journal

ENTREPRENEURSHIP AND SUSTAINABILITY ISSUES

ISSN 2345-0282 (online) http://jssidoi.org/jesi/

2018 Volume 5 Number 4 (June)

http://doi.org/10.9770/jesi.2018.5.4(6)

Zhao, Y.; Zhou, W.; Huesig, S.; Vanhaverbeke, W. 2010. Environment, Network Interactions and Innovation Performance of Industrial Clusters: Evidences from Germany, Netherlands and China, International Journal of Innovation Management 14(1): 1-18.

Zhu, J. 2014. Quantitative Models for Performance Evaluation and Benchmarking. Cham: Springer.

Žižka, M.; Hovorková Valentová, V.; Turčok, L. 2016. Performance evaluation of Czech innovative companies: data envelopment analysis approach, International Journal of Strategic Property Management 20(4), 427-438. http://doi.org/10.3846/1648715X.2016.1239592

Žižka, M. 2017. Use of Malmquist Index in Evaluating Performance of Companies in Cluster. 35th International Conference Mathematical Methods In Economics, Conference Proceedings. Ed. by Pražák, P. September 13-15, Hradec Králové, Czech Republic. Hradec Králové: Gaudeamus, 878-883.

\section{Aknowledgements}

The research was conducted with the financial support of Czech Science Foundation grant no. GA18-01144S entitled "An empirical study of the existence of clusters and their effect on the performance of member enterprises".

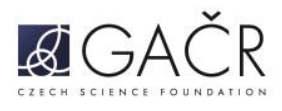

Miroslav ŽIŽKA is the dean of the Faculty of Economics at the Technical University of Liberec. He gained a PhD in the field of Organization and Business Management at the Technical University of Liberec in 2002. He was appointed professor at the proposal of Tomas Bata University in Zlin in the field of Management and Economics in 2015. Research interests: quantitative methods in economics and management, performance and competitiveness of clusters.

ORCID ID: https://orcid.org/0000-0002-7804-3954

Vladimíra HOVORKOVÁ VALENTOVÁ is the Ph.D. lecturer of basic and advanced courses of statistics. Her field of research interest is the descriptive statistics and sample surveys. She cooperated with the Academic Coordination Centre in Euroregion Nisa many years and joined or led some projects with the Polish partner from Jelenia Góra. She also has a strong cooperation with prof. Sigitas Vaitkevičius from Kaunas University of Technology. She is focused on the application of statistical methods in economics.

ORCID ID: https://orcid.org/0000-0001-5718-315X

Natalie PELLONEOVÁ is the doctoral student of economics study programme at Faculty of Economics, Technical University of Liberec, CZ. Her work is focused on quantitative methods in management. She further focuses on research in the area of business networks and clusters. Research interests: operations research; networks and clusters; business logistics.

ORCID ID: https://orcid.org/0000-0003-3566-0677

Eva ŠTICHHAUEROVÁ is Ph.D., assistant professor at the Faculty of Economics, Technical University of Liberec. Research interests: business administration and management; quantitative methods in management; lean management.

ORCID ID: https://orcid.org/0000-0001-7201-678X

Register for an ORCID ID:

https://orcid.org/register

Copyright (C) 2018 by author(s) and VsI Entrepreneurship and Sustainability Center

This work is licensed under the Creative Commons Attribution International License (CC BY).

http://creativecommons.org/licenses/by/4.0/

(c) (i) Open Access 